\title{
The Structure of Triphenylgermanium Hydroxide
}

\author{
By George Ferguson and John F. Gallagher \\ Department of Chemistry \& Biochemistry, University of Guelph, Guelph, Ontario, Canada N1G $2 W 1$ \\ Denis Murphy and Trevor R. Spalding \\ Chemistry Department, University College, Cork, Ireland \\ and Christopher Glidewell and H. Diane Holden \\ Chemistry Department, The University, St Andrews, Fife KY16 9ST, Scotland
}

(Received 16 October 1991; accepted 20 December 1991)

\begin{abstract}
C}_{18} \mathrm{H}_{16} \mathrm{GeO}, M_{r}=320.9$, triclinic, $P \overline{1}, a=$ 15.408 (6), $\quad b=19.974$ (7), $\quad c=23.264$ (11) $\AA, \quad \alpha=$ $107.78(4), \quad \beta=103.54(4), \quad \gamma=101.51(3)^{\circ}, \quad V=$ 6338 (5) $\AA^{3}, Z=16, D_{x}=1.34 \mathrm{~g} \mathrm{~cm}^{-3}, \lambda($ Mo $K \alpha)=$ $0.71073 \AA, \quad \mu=19.1 \mathrm{~cm}^{-1}, \quad F(000)=2624, \quad T=$ $293 \mathrm{~K}, R=0.055$ for 6846 observed reflections. The eight independent molecules in the asymmetric unit form two independent $\mathrm{O}-\mathrm{H} \cdots \mathrm{O}$ hydrogen-bonded tetramers with the $\mathrm{O}$ atoms in a flattened tetrahedral arrangement [hydrogen-bond distances in the range 2.609 (11) to 2.657 (11) $\AA$ ]. The Ge atoms are tetrahedrally coordinated with mean $\mathrm{Ge}-\mathrm{O} 1.791$ (7) and $\mathrm{Ge}-\mathrm{C} 1.931(8) \AA$.
\end{abstract}

Introduction. The title compound was obtained from the slow hydrolysis of $\mathrm{PhB}\left(\mathrm{OGePh}_{3}\right)_{2}$ which had been previously prepared from the reaction of one equivalent of $\mathrm{PhB}(\mathrm{OH})_{2}$ with two equivalents of $\mathrm{Ph}_{3} \mathrm{GeBr}$ in ether. Recrystallization from petroleum ether $\left(100-120^{\circ} \mathrm{C}\right)$ in aerobic conditions yielded colourless crystals of $\mathrm{Ph}_{3} \mathrm{GeOH}$.

Experimental. A colourless block crystal measuring $0.5 \times 0.6 \times 0.4 \mathrm{~mm}$ was mounted on a glass fibre with its long axis roughly parallel to the $\varphi$ axis of the goniometer. Cell dimensions and crystal orientation matrix were determined on a CAD-4 diffractometer with graphite-monochromated Mo $K \alpha$ radiation, from a least-squares refinement of the setting angles of 25 reflections in the range $30<2 \theta<32^{\circ}$. Intensities of reflections with indices $h-19$ to $19, k 0$ to 25 , $l-29$ to 29 and with $2<2 \theta<43^{\circ}$ measured; $\omega-2 \theta$ scans; $\omega$-scan width $(0.8+0.35 \tan \theta)^{\circ}$. Intensities of three reflections were measured at $2 \mathrm{~h}$ intervals; these standards remained constant within experimental error throughout data collection. In all, we measured 14490 reflections, 6846 with $I>3 \sigma(I)$ were labelled observed and used in structure solution and refinement. Space group $P \overline{1}$ deduced from cell reduc-

0108-2701/92/071228-04\$06.00 tion and refinement. Data were corrected for Lorentz and polarization effects. The structure was solved by direct methods. All non- $\mathrm{H}$ atoms were located from an $E$ map and refined anisotropically. All phenyl groups were refined as planar hexagons $(\mathrm{C}-\mathrm{C} 1.395$, $\mathrm{C}-\mathrm{H} 0.95 \AA$ ). The hydroxyl $\mathrm{H}$ atoms could not be unequivocally located; in the volume element between each pair of $\mathrm{O}$ atoms in each tetramer there was clear evidence for electron density between the $\mathrm{O}$ atoms - but not distinct well resolved maxima. We concluded that the pattern of four $\mathrm{O}-\mathrm{H} \cdots \mathrm{O}$ hydrogen bonds in each tetramer was probably disordered. The final block-diagonal refinement cycles on $F$ included 1153 variable parameters, $R=0.055, w R=$ 0.071, goodness of fit $1.39, \quad w=1 /\left[\sigma^{2}\left(F_{o}\right)+\right.$ $0.0015\left(F_{o}\right)^{2}$. Max. shift/e.s.d. $<0.02$; density range in final difference map from -0.49 to $0.53{\mathrm{e} \AA^{-3}}^{-3}$ between $\mathrm{O}$ atoms. Scattering factors and anomalousdispersion corrections from International Tables for $X$-ray Crystallography (1974, Vol. IV). All calculations were performed on a Silicon Graphics 4D-380 computer using the NRCVAX suite of programs (Gabe, Le Page, Charland, Lee \& White, 1989). Atomic coordinates and selected bond lengths, angles and dihedral angles are given in Tables 1 and 2 , respectively. ${ }^{*}$ Fig. 1 is a view of one tetramer prepared using ORTEPII (Johnson, 1976).

Discussion. A recent paper describes the structure of $\mathrm{Ph}_{3} \mathrm{SiOH}$ at $208 \mathrm{~K}$ and reports that the $\mathrm{Ge}$ compound is isomorphous but gives no metrical data for

\footnotetext{
* Full details of molecular dimensions, calculated H-atom coordinates, anisotropic thermal parameters, mean-planes data, selected torsion angles and a list of structure factors have been deposited with the British Library Document Supply Centre as Supplementary Publication No. SUP 54985 (47 pp.). Copies may be obtained through The Technical Editor, International Union of Crystallography, 5 Abbey Square, Chester CH1 2HU, England. [CIF reference: MU0293]
}

(C) 1992 International Union of Crystallography 
Table 1. Positional and thermal parameters and their

Table 1 (cont.)

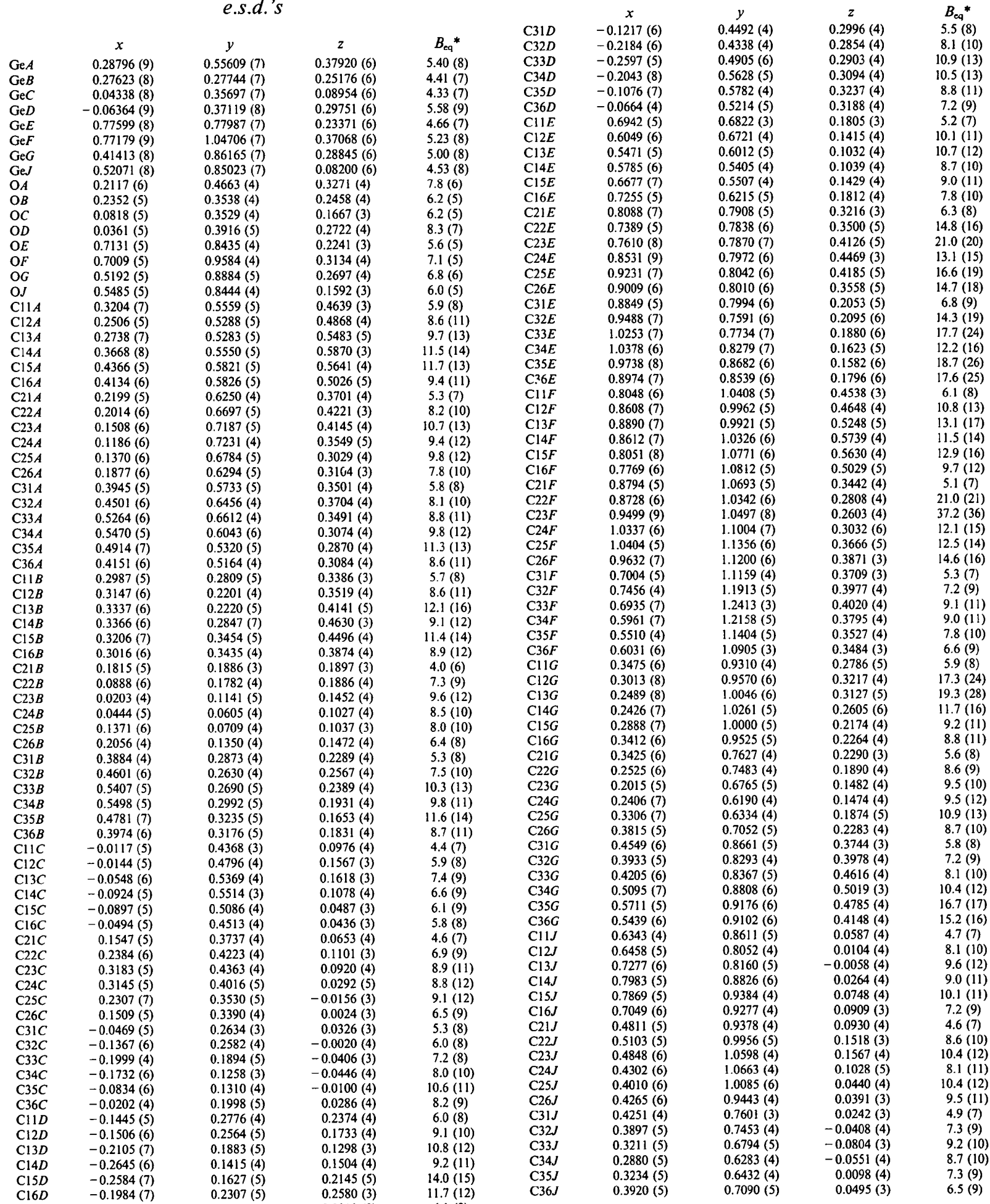

the $\mathrm{Ph}_{3} \mathrm{GeOH}$ molecules (Puff, Braun \& Reuter, 1991). $\mathrm{Ph}_{3} \mathrm{GeOH}$ crystallizes with eight independent molecules in the asymmetric unit; these are arranged in two similar independent hydrogen-bonded tetra- 
Table 2. Selected bond lengths $(\AA)$ and angles $\left(^{\circ}\right)$

\begin{tabular}{|c|c|c|c|c|c|c|c|c|}
\hline & $y=A$ & $\boldsymbol{B}$ & $C$ & $D$ & $E$ & $F$ & $G$ & $J$ \\
\hline $\mathrm{Ge}-\mathrm{O} y$ & $1.798(8)$ & $1.794(7)$ & $1.787(7)$ & $1.788(7)$ & $1.780(7)$ & $1.791(7)$ & $1.796(7)$ & $1.792(7)$ \\
\hline $\mathrm{Ge}-\mathrm{Clly}$ & $1.918(8)$ & $1.945(8)$ & $1.932(8)$ & $1.914(6)$ & $1.934(6)$ & $1.931(9)$ & $1.918(10)$ & $1.942(8)$ \\
\hline $\mathrm{Ge}-\mathrm{C} 21 \mathrm{y}$ & $1.921(9)$ & $1.944(5)$ & $1.926(8)$ & $1.932(8)$ & $1.919(7)$ & $1.918(9)$ & $1.945(6)$ & $1.930(8)$ \\
\hline \multirow[t]{2}{*}{$\mathrm{Ge}-\mathrm{C} 31 \mathrm{y}$} & $1.925(9)$ & $1.915(8)$ & $1.942(6)$ & $1.940(10)$ & $1.955(10)$ & $1.925(9)$ & $1.920(7)$ & $1.938(5)$ \\
\hline & $y=A$ & $B$ & $C$ & $D$ & $E$ & $F$ & $G$ & $J$ \\
\hline $\mathrm{O} y-\mathrm{Ge}-\mathrm{C} 1 \mathrm{y}$ & $107.4(4)$ & $108.7(4)$ & $107.5(4)$ & $107.2(4)$ & $107.6(3)$ & $108.7(4)$ & $106.2(4)$ & $107.5(4)$ \\
\hline $\mathrm{Oy}-\mathrm{Ge}-\mathrm{C} 21 y$ & $106.7(3)$ & $107.1(3)$ & $104.7(4)$ & $106.8(4)$ & $107.8(4)$ & $105.0(4)$ & $108.5(4)$ & $104.9(4)$ \\
\hline $\mathrm{O} y-\mathrm{Ge}-\mathrm{C} 31 \mathrm{y}$ & $107.1(4)$ & $106.7(4)$ & $108.3(3)$ & $107.5(4)$ & $108.7(4)$ & $108.7(3)$ & $105.3(4)$ & $107.1(4)$ \\
\hline $\mathrm{C} 11 y-\mathrm{Ge}-\mathrm{C} 21 \mathrm{y}$ & $112.4(4)$ & $112.9(3)$ & $112.9(4)$ & $111.2(3)$ & $110.3(4)$ & $111.7(4)$ & $110.0(3)$ & $110.7(4)$ \\
\hline $\mathrm{C} 11 y-\mathrm{Ge}-\mathrm{C} 31 \mathrm{y}$ & $112.9(4)$ & $111.8(4)$ & $111.5(3)$ & $112.1(3)$ & $109.5(4)$ & $108.9(4)$ & $113.4(4)$ & $111.7(3)$ \\
\hline $\mathrm{C} 21 y-\mathrm{Ge}-\mathrm{C} 31 y$ & $109.9(4)$ & $109.3(3)$ & $115.5(3)$ & $111.7(4)$ & $112.8(4)$ & $113.6(4)$ & $112.0(4)$ & $114.4(3)$ \\
\hline \multicolumn{9}{|c|}{ Hydrogen-bond contacts $(\AA)$} \\
\hline$O A \cdots O B$ & 2.609 (11) & $\mathrm{O} A \cdots \mathrm{OD}$ & $2.604(12)$ & $O B \cdots O C$ & 2.626 & & $O C \cdots O D$ & $2.642(11)$ \\
\hline$O E \cdots O F$ & 2.657 (11) & $\mathrm{OE} \cdots \mathrm{OJ}$ & $2.636(10)$ & $O F \cdots O G$ & 2.657 & & OG $\cdots$ OJ & $2.628(10)$ \\
\hline \multicolumn{9}{|c|}{$\mathrm{O} \cdots \mathrm{O}$ distances across the tetramer $(\AA)$} \\
\hline $\mathrm{OA} \cdots \mathrm{OC}$ & $3.548(11)$ & $O B \cdots O D$ & $3.446(11)$ & $\mathrm{O} E \cdots \mathrm{OG}$ & 3.580 & & $\mathrm{O} F \cdots \mathrm{OJ}$ & $3.536(10)$ \\
\hline \multicolumn{9}{|c|}{ Hydrogen-bond angles around the tetramer $\left({ }^{\circ}\right)$} \\
\hline $\begin{array}{l}\mathrm{OA} \cdots \mathrm{OB} \cdots \mathrm{OC} \\
\mathrm{OF} \cdots \mathrm{OE} \cdots \mathrm{OJ}\end{array}$ & $\begin{array}{l}85.3(3) \\
83.8(3)\end{array}$ & $\begin{array}{l}\mathrm{O} B \cdots \mathrm{O} C \cdots \mathrm{O} D \\
\mathrm{O} E \cdots \mathrm{O} F \cdots \mathrm{O} G\end{array}$ & $\begin{array}{l}81.7(3) \\
84.7(3)\end{array}$ & $\begin{array}{l}\mathrm{O} B \cdots \mathrm{O} A \\
\mathrm{O} F \cdots \mathrm{O} \cdot\end{array}$ & $\begin{array}{l}82.8 \\
84.0\end{array}$ & & $\begin{array}{l}\mathrm{O} A \cdots \mathrm{O} D \cdots \mathrm{O} C \\
\mathrm{O} E \cdots \mathrm{O} J \cdots \mathrm{O} G\end{array}$ & $\begin{array}{l}85.1(3) \\
85.7(3)\end{array}$ \\
\hline
\end{tabular}

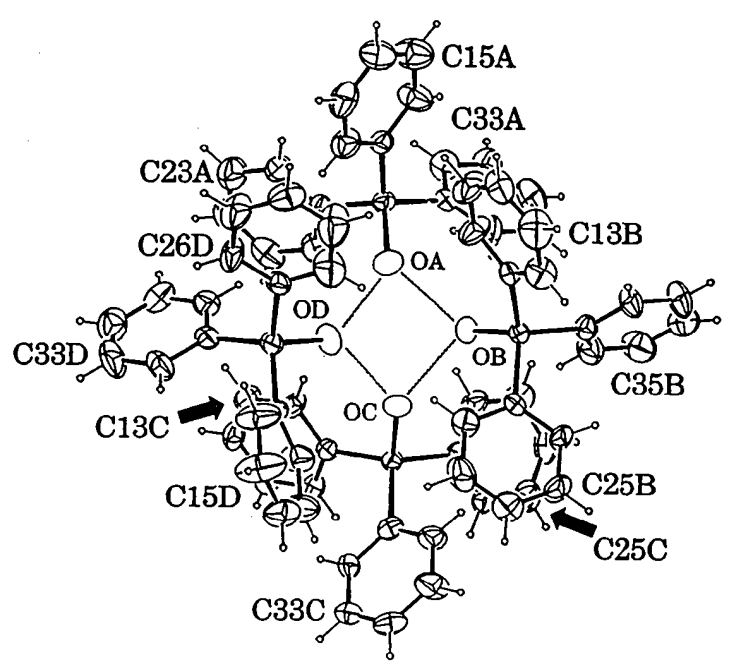

Fig. 1. A view of one of the $\mathrm{Ph}_{3} \mathrm{GeOH}$ tetramers showing the numbering scheme; the other tetramer is similarly numbered with rings labelled $E, F, G$ and $J$. The thermal ellipsoids shown for the $\mathrm{Ge}, \mathrm{O}$ and $\mathrm{C}$ atoms are at the $25 \%$ probability level.

mers, one of which is shown in Fig. 1. The arrangement of phenyl rings in the $\mathrm{Ph}_{3} \mathrm{GeOH}$ moieties corresponds to distorted propeller conformations, with the dihedral angles between the $\mathrm{O}-\mathrm{Ge}-\mathrm{C}$ and Ge-phenyl planes being in the range 1.1 (4) to $70.3(4)^{\circ}$. The arrangement of the $\mathrm{O}$ atoms in these tetramers is best described as a flattened tetrahedron as depicted in Fig. 2. The angle between the planes through $\mathrm{O} A, \mathrm{O} B, \mathrm{O} C$ and $\mathrm{O} A, \mathrm{O} D, \mathrm{O} C$ is $126.5(5)^{\circ}$ $\left[130.5(4)^{\circ}\right.$ for the corresponding interplanar angle between $\mathrm{O} E, \mathrm{O} F, \mathrm{O} G$ and $\mathrm{O} E, \mathrm{O} J, \mathrm{O} G$.

The $\mathrm{Ge}-\mathrm{O}$ bond lengths in $\mathrm{Ph}_{3} \mathrm{GeOH}$ are in the range 1.780 (7) to $1.798(8) \AA$ with a mean value of $1.791(8) \AA$. Published $\mathrm{Ge}-\mathrm{O}$ bond lengths span the

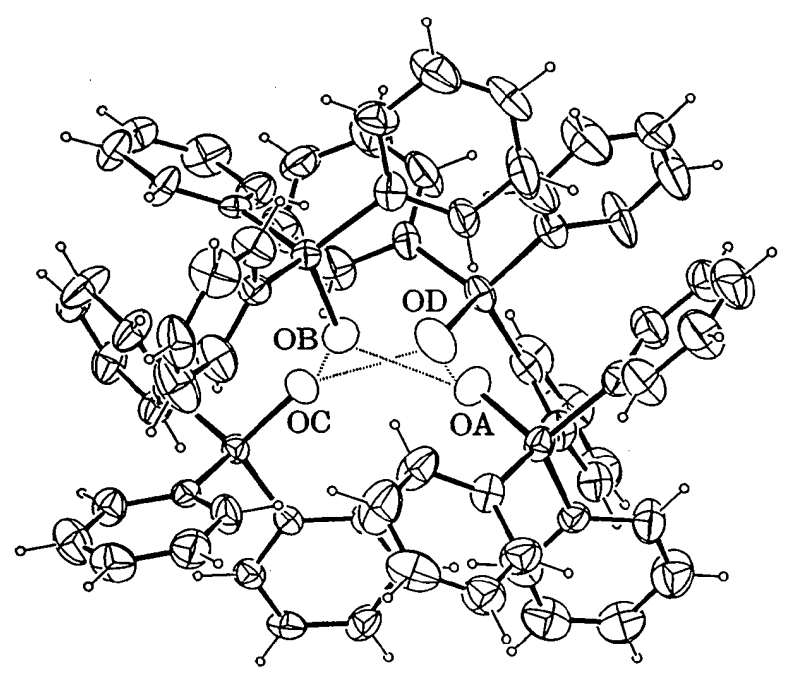

Fig. 2. A view of one of the $\mathrm{Ph}_{3} \mathrm{GeOH}$ tetramers showing the flattened tetrahedral arrangement of the $\mathrm{O}$ atoms.

range $1.718(3) \AA$ in $\mathrm{Ph}_{3} \mathrm{GeOSiPh}_{3}$ (Morosin \& Harrah, 1981) to $1.86(1) \AA$ in $\mathrm{Ph}_{3} \mathrm{GeOCOCF}$ (Glidewell \& Liles, 1983). The oxide derived from $\mathrm{Ph}_{3} \mathrm{GeOH}$ (i.e. $\mathrm{Ph}_{3} \mathrm{GeOGePh}$ ) has a mean $\mathrm{Ge}-\mathrm{O}$ bond length of 1.767 (2) $\AA$ (Glidewell \& Liles, $1978 a$ ); essentially the same value [1.766 (4) $\AA$ ] was found in $\mathrm{H}_{3} \mathrm{GeOGeH}_{3}$ determined by electron diffraction (Glidewell, Rankin, Robiette, Sheldrick, Beagley \& Cradock, 1970).

The $\mathrm{Ge}-\mathrm{C}$ distances in $\mathrm{Ph}_{3} \mathrm{GeOH}$ are in the range 1.914 (6) to $1.955(10) \AA$, mean value 1.931 (20) $\AA$. For comparison, the $\mathrm{Ge}-\mathrm{C}$ bond lengths in $\mathrm{Ph}_{3} \mathrm{GeOGePh}_{3}$ range from 1.934 (5) to 1.951 (5) $\AA$ with a mean value 1.942 (3) $\AA$; in $\mathrm{Ph}_{4} \mathrm{Ge}$ the single value of 1.957 (4) $\AA$ is reported (Karipides \& Haller, 1972). 
The structural determination of $\mathrm{Ph}_{3} \mathrm{GeOH}$ is part of a series for the Group $14 \mathrm{Ph}_{3} M O H$ molecules $(M$ $=\mathrm{C}, \mathrm{Si}, \mathrm{Ge}, \mathrm{Sn}, \mathrm{Pb}$ ). Crystals of $\mathrm{Ph}_{3} \mathrm{COH}$ (Ferguson, Gallagher, Glidewell, Low \& Scrimgeour, 1992) are trigonal, $R \overline{3}$, with 1.33 molecules in the asymmetric unit and consist of hydrogen-bonded pyramidal tetramers with one molecule on a threefold axis and the other three lying around it. The $\mathrm{Ph}_{3} \mathrm{SiOH}$ structure is isomorphous with $\mathrm{Ph}_{3} \mathrm{GeOH}$. Both $\mathrm{Ph}_{3} \mathrm{SnOH}$ and $\mathrm{Ph}_{3} \mathrm{PbOH}$ have structures consisting of zigzag chains of planar $\mathrm{Ph}_{3} M(M=\mathrm{Sn}, \mathrm{Pb})$ groups joined by $\mathrm{OH}$ groups giving trigonal bipyramidal geometry at $M$ (Glidewell \& Liles, 1978b).

GF thanks NSERC Canada for Grants in Aid of Research.

\section{References}

Ferguson, G., Gallagher, J. F., Glidewell, C., Low, J. N. \& SCRIMGEOUR, S. N. (1992). Acta Cryst. C48, 1272-1275.

Gabe, E. J., Le Page, Y., Charland, J. P., Lee, F. L. \& White, P. S. (1989). J. Appl. Cryst. 22, 384-389.

Glidewell, C. \& Liles, D. C. (1978a). Acta Cryst. B34, 119-124. Glidewell, C. \& Liles, D. C. (1978b). Acta Cryst. B34, 129-134. Glidewell, C. \& Liles, D. C. (1983). J. Organomet. Chem. 243, 291-297.

Glidewell, C., Rankin, D. W. H., Robiette, A. G., Sheldrick, G. M., Beagley, B. \& Cradock, S. (1970). J. Chem. Soc. A, pp. 315-317.

JoHNSON, C. K. (1976). ORTEPII. Report ORNL-5138. Oak Ridge National Laboratory, Tennessee, USA.

KaRipides, A. \& Haller, D. A. (1972). Acta Cryst. B28, 2889 2892.

Morosin, B. \& Harrah, L. A. (1981). Acta Cryst. B37, 579-586.

Puff, H., Braun, K. \& Reuter, H. (1991). J. Organomet. Chem. 409, 119-129.

Acta Cryst. (1992). C48, 1231-1233

\title{
Structure of catena-Poly $\left[\left\{\left(2,2^{\prime}\right.\right.\right.$-bipyridyl)(diperchlorato)copper(II) $\}-\mu-4,4^{\prime}$-bipyridyl]
}

\author{
By Chenggang Chen, Duanum Xu,* Yuanzhi Xu and Chaorong Cheng \\ Department of Chemistry, Zhejiang University, Hangzhou, People's Republic of China \\ AND RoNGGUO LING \\ Central Laboratory, Hangzhou University, Hangzhou, People's Republic of China
}

(Received 4 September 1991; accepted 3 December 1991)

\begin{abstract}
Cu}\left(\mathrm{C}_{10} \mathrm{H}_{8} \mathrm{~N}_{2}\right)\left(\mathrm{C}_{10} \mathrm{H}_{8} \mathrm{~N}_{2}\right)\left(\mathrm{ClO}_{4}\right)_{2}\right], \quad M_{r}=$ 574.5, orthorhombic, Pbcn, $a=12.413$ (3), $b=$ 14.645 (3), $c=12.287$ (2) $\AA, V=2233.6$ (8) $\AA^{3}, Z=$ $4, D_{x}=1.708 \mathrm{~g} \mathrm{~cm}^{-3}, \lambda($ Mo $K \alpha)=0.71069 \AA, \mu=$ $13.12 \mathrm{~cm}^{-1}, F(000)=1164$, room temperature, $R=$ 0.050 and $w R=0.049$ for 1498 observed reflections. The coordination around $\mathrm{Cu}^{\mathrm{II}}$ is an elongated distorted octahedron. Two $\mathrm{N}$ atoms of 2,2'-bipyridyl and two $\mathrm{N}$ atoms from two 4,4'-bipyridyls form the equatorial coordination plane, and two perchlorate ions occupy the axial sites. The $4,4^{\prime}$-bipyridyl ligand bridges neighbouring $\mathrm{Cu}^{\mathrm{II}}$ atoms to form polymeric chains along the $c$ axis in the crystal. The rings of 4,4'-bipyridyl are coplanar and make a dihedral angle of $114^{\circ}$ with the equatorial coordination plane; the 4,4'-bipyridyl may provide a pathway for magnetic superexchange interaction between the adjacent $\mathrm{Cu}^{\mathrm{II}}$ atoms.
\end{abstract}

Introduction. In the last decade, a number of binuclear transition-metal complexes bridged by heterocyclic aromatic diamines have been investigated as

* To whom correspondence should be addressed.

0108-2701/92/071231-03\$06.00 models of metalloenzymes (Matsumoto, Ooi, Nakao, Mori \& Nakahara, 1981; Richardson \& Hatfield, 1975). In some imidazolate or pyrazine-bridged complexes, spin-spin exchange interactions, propagated by the bridging ligand between the adjacent metal ions, have been observed, and studies on the molecular and crystal structures of those complexes have shown the relationship between structure and magnetic property (Coronado, Drillon \& Beltran, 1984; $\mathrm{Xu}$, Chen, Xu, Cheng, Chen \& Tang, 1991). Recently, a series of novel $\mathrm{Cu}^{\mathrm{II}}$ complexes bridged by 4,4'-bipyridyl ligands have been synthesized, and studies on EPR spectra showed evidence of superexchange interaction propagated by the $4,4^{\prime}$ bipyridyl ligand in the title complex, but no interaction in the others (Chen, 1989). In order to investigate the structural reason for the differences in the magnetic properties, the crystal structures of these complexes have been determined by means of X-ray analysis.

Experimental. 2,2'-Bipyridyl (2 mmol) and 4,4'bipyridyl $(2 \mathrm{mmol})$ were dissolved in ethanol, and then the solution was mixed with an aqueous solu-

(C) 1992 International Union of Crystallography 